\title{
GUILDS AND COMPETITION: A RESPONSE TO OBJECTIONS OF LAISSEZ FAIRE
}

\section{LUKÁŠ AUGUSTIN MÁSLO}

\begin{abstract}
:
This paper offers a critique of laissez-faire objections to the guild system from the perspective of Catholic social teaching a presents the economic reasons for a restoration of the guild system as a functional economic model. The laissez-faire argument is that 1 ) the free competition on the supply side is in the best interest of the consumer, 2) each member of the society is a consumer, 3) ergo: free competition on the supply side is a common good, i. e. a goal which the state should follow. The author argues that 1 ) unlike majority of goods and services, two goods are becoming scarcer as a result of free competition on the supply side: time and land, 2) consumers which prefer consumption of leisure time and land are worse off as a result of free competition on the supply side, 3 ) ergo: the conclusion that free competition on the supply side is always a common good is invalid. According to the author, leisure time and land are essential for a good operation of a well-functioning family which is essential for a well-functioning state. In this connection, the author contends that the primary goal and raison d'etre of the guilds is control of the entrance of new producers to the industry, so that the incumbents who want to pay just (family) wages and/or prefer leisure time necessary for operation of a well-functioning family are not forced to change their behavior by the competitive pressure of the newcomers. Besides, a control of the entrance will limit the pressure to lowering wages below the level of the just (family) wage. To the objection of "no free lunch" the author responds: yes, the employers are facing a trade-off. In exchange for a possibly high but uncertain profit margin they will receive a lower but certain profit margin. To the objection of allocational inefficiency and economic stagnation resulting from suppressing external innovations, the author responds: 1) an external innovator can have his discovery patented and instead of the transitory entrepreneurial profit enjoy the incomes from the licenses; 2 ) the competitive pressure is only one possible drive of the economic growth, another drive is the human laziness which is constant across the economic systems.
\end{abstract}

\section{Keywords:}

consumer, competition, structural changes, guilds, laissez faire, social justice, just wage

JEL Classification: K23, 038, P41

\section{Authors:}

LUKÁŠ AUGUSTIN MÁSLO, Vysoká škola ekonomická v Praze, Czech Republic, Email: lukas.maslo@vse.cz

\section{Citation:}

LUKÁŠ AUGUSTIN MÁSLO (2021). Guilds and Competition: A Response to Objections of Laissez Faire. International Journal of Social Sciences, Vol. X(2), pp. 1-14., 10.52950/SS.2021.10.2.001 


\section{Introduction}

According to laissez-faire proponents ${ }^{1}$, consumption is the only goal of production. Here originates their postulate that the consumer should be the captain of the economy and the consumer's preferences should determine the allocation of scarce resources and production factors. A consumer benefits from a reduction of production cost, of course. The wages are usually the most important factor of production. ${ }^{2}$ The lowering of wages below the level of the family wage is a violation of the legal or social justice, though (see Burke, 2010, p. 301; for a detailed exposition see Máslo, 2021, pp. 36-40). The above mentioned brings up the following questions. If the consumer's well-being comes into conflict with the requirement of justice, which of these two goods should be preferred? Next, each employer is bound in conscience to pay the just wage. Why, then, the Catholic social teaching (Rerum Novarum, 3, 49; Quadragesimo Anno, 83, 85, 86, 87) expresses its support to the guild system? I mean, an employer does not need to be a member of a guild to pay the just wage. What is the raison d'etre of the guilds, then? And how to settle the objection that the guild system, as a result of the competition control, leads to a stagnation of the economy? In this paper, I will offer a critique of laissez-faire objections to the guild system from the perspective of Catholic social teaching a present the economic reasons for a restoration of the guild system as a functional economic model.

\section{Goals of Production}

Laissez-faire proponents, as it is well-known, emphasize that the goal of all production is consumption. ${ }^{3}$ From this, a postulate follows that all productive processes have the consumer's well-being as their ultimate end. Taking into account that everybody is a consumer, a conclusion cannot be avoided that an economic system which maximizes the consumer's well-being is a common good, something a state should strive for. Economics teaches us that the consumer's well-being is being maximized in a system of free competition on the supply side. The producers compete with each other who will satisfy the consumer's wishes in a better and cheaper way. Profit is a reward for the service to the consumer. A byproduct of the endeavor to maximize the profit is maximization of quality, minimization of price, maximization of the consumer's well-

\footnotetext{
${ }^{1}$ Also known as economic liberals in Europe or neoliberals in both the U.S. and Europe (see e. g. Keynan, 2016). I did my best to avoid using the term "liberalism" throughout this paper because of ambiguous meaning of this term, not only in dependence on the country in which it is used (e. g. different meaning of the term in the Anglo-Saxon countries) but also on the context (the term "liberal" in political sciences refers to neomarxist ideology - see e. g. Abbott, 2019; the term "liberal" in economic science refers to the values of the free market or laissez faire).

${ }^{2}$ It is the competition of employers for the labor force which prevents the wages from decreasing to zero. If the wage were zero, the excess of demand over the supply would make the employers outbid each other until the wage would increase to the level of the value of the marginal product of the last employed laborer. In the perfectly competitive labor market, though, the market-clearing wage will most probably fall short of the family wage which the employer is obliged to pay to each employee on the grounds of the legal or social justice. So, a competition of laborers for jobs keeps the wages under the level of the family wage - with the given labor demand. However, what would happen if the employers decided that they want to pay family wages - at the expense of their own profits? Then, the labor demand would increase and the market-clearing wage would increase to the socially just level. Until this happens, the consumer benefits from the competition of the employees which pushes the wages down to the level of the value of the marginal product of the last employed laborer.

${ }^{3}$ Consumption is the sole end and purpose of all production; and the interest of the producer ought to be attended to only so far as it may be necessary for promoting that of the consumer. The maxim is so perfectly self evident that it would be absurd to attempt to prove it. (Smith, 1776, Book IV, Ch. VIII, 48).
} 
being, minimization of costs and maximization of efficiency of allocation of the natural resources. The above said implies that only an economic idiot or a reactionary could afford to criticize a system of free competition. However, when Pius XI in his encyclical Quadragesimo Anno recommends a reconstruction of the social and economic order based on a creation of guilds, he emphasizes the common good, as well:

It is easily deduced from what has been said that the interests common to the whole Industry or Profession should hold first place in these guilds. The most important among these interests is to promote the cooperation in the highest degree of each industry and profession for the sake of the common good of the country. (Quadragesimo Anno, 85).

The guild system, though, in a sense, represents an anti-thesis of the principle of the supremacy of the consumer whose well-being is considered the common good by the laissez-faire advocates. According to the Catholic social teaching, is the consumer's well-being not the common good, then? If not, what is?

Let us examine the validity of the premises and conclusions of the laissez-faire ideology. The goal of all production is consumption. Yes, that is true, indeed. Obviously, there is no sense in producing something which nobody is going to use. The free competition is in the best interest of the consumer because it reduces the prices and enhances the quality of the produced goods. Since each member of the community is a consumer, it is in the best interest of the community to support the institutional environment of the free competition. That sounds like a bullet-proof argument. However, there are at least two goods about which the above said is not true. As a matter of fact, there are at least two goods about which we can draw the very opposite conclusion, i. e. the institutional environment of the free competition on the supply side makes them scarcer and, as a result, more expensive. These two goods are time and land. Why time? Let us take a closer look at the free competition. What does it mean? To keep doing your best to provide a cheaper and better product than your competitor. To achieve this, you need to keep finding ways to reduce the production costs permanently. To be better than your competitor in terms of production costs and quality, you need to sacrifice yourself for the goal of the service to the customer. This means sacrificing your energy, your talent and your time to the customer. Market competition is like a never-ending race. You cannot slow down or you will loose. It does not matter if you are a self-employed entrepreneur, employing entrepreneur or an employee. The time shrinks. If you are an employee, the labor market competition forces you to be prepared to sacrifice more to your work than someone who is breathing on your back and who is eager to replace you in your job. If you don't want to work on Sundays and on holidays, there is always someone waiting out there on the street who will. That time is getting scarcer in the institutional environment of the free competition is not a phenomenon emerging in the long run. It is a phenomenon which emerges simultaneously with the emergence of the free competition. Why land? Similarly as time, land is a resource which cannot be extended. The quantities of both time and land have an absolutely inelastic supply. The free competition on the side of supply increases the demand for land. Like this, the proportion between the demand of consumers and demand of producers is being diverted towards the productive demand. A newcomer to the industry who has a great business plan can afford to outbid the incumbents when he demands the factor of land. Unless the competition on the side of supply is restricted, there is always be a newcomer who will be willing to outbid the incumbents and the consumers.

A laissez-faire advocate says that everybody is a consumer. Yes, but some consumers prefer the consumption of leisure time and land which are consumption goods as well. These two goods are getting scarcer as a result of the free competition on the supply side. Real income of 
consumers is increasing with the price reductions. Price reductions are the result of the free competition on the supply side. So, free competition on the supply side is increasing the real income of consumers. Everybody is a consumer. So, free competition on the supply side is increasing the real income of the population. Real income of consumers of leisure time and land is decreasing, though, as a result of the free competition on the supply side. Not all consumers have strong preferences of leisure time and land in their consumption bundle. However, some consumers do. These consumers are made worse off by the free competition on the supply side, then. If a man performs labor which is mixed with his own capital, all fruits born from his capital and labor belong to him. If a man performs labor which is mixed with someone else's capital, a problem of just distribution of the fruits of the production arises. (See Quadragesimo Anno, 53). In principle, there are three options: 1) a man which is supplying the labor takes the risk of failure upon himself and pays a reward (a rent) to the owner of the employed capital for the service of this capital. 2) a man which is supplying the capital takes the risk of failure upon himself and pays a reward (a wage) to the owner of the employed labor for the service of this labor. 3) the owner of the labor and owner of the capital will share the risk, i. e. they will be partners. The second option implies the problem of the just wage. Economic system which is maximizing the consumer's well-being is a common good. ${ }^{4}$ Yes, but the well-being of some consumers is being maximized in the institutional environment of free competition on the supply side, while the well-being of other consumers is being maximized in the institutional environment of restricted competition. So, the inference that free competition on the supply side is a common good in invalid.

Besides, the system of free competition may not - and probably will not - ensure the payment of just wages. Let us assume a group of entrepreneurs - employers who want to pay just (family) wages to their employees. Then, a newcomer to the industry comes with a new cost-reducing production technology which allows him to reduce the price of the product. Which choices do the incumbent employers have? They don't have access the new technology, so, as long as they want to remain price competitive, they will either reduce their own profits and preserve the wages at the family level or they will preserve their profits and reduce the wages. If they reduce their own profits below the adequate level, it cannot be for long. Sooner or later they will leave the industry and their employees will loose their jobs. It is the pressure of the newcomer what makes the incumbents abandon their resolution to pay just (family) wages or leave the industry. So, if the consumer's well-being comes into conflict with the goal of achieving justice, should the consumer's well-being take precedence? On the grounds of what? (Compare Worland, 1981 , p. 278). Next, the system of free competition on the supply side is a result of the victory of the ideology of individualism, partly, but partly, from a retroactive perspective, it leads to a deep rooting of the individualist ideology in the human thinking. Ask a café owner what another café owner in the same street is to him. The answer will be: a competitor. Two competitors strive for the same thing. At the same time, a success of one excludes the success of the other, very often. In the context of the individualist ideology of laissez-faire, the competition is a zero-sum game. ${ }^{5}$ At this moment, we can hear the yelling of the laissez-faire opponent: the defeated

\footnotetext{
${ }^{4}$ Brown (1996, p. 93) mentions the following opinion as a feature of modern economics: the common good results from an "invisible hand" which operates through the individual pursuits of competitors.

5 Yuengert (1996, p. 107) disproves the argument of some laissez-faire advocates that the free-market environment is forming a character of market participant positively, exactly by pointing out the negative effect of the free competition: participants in the market [...] are often in competition with one another, and competition does not provide the same incentives to virtue [as the seller-customer relation does, L. A. M.]. Producers of the same product are not necessarily nice to each other, and workers who compete for the same job (immigrants and native workers, for example) have every incentive to undercut and demonize each other [...].
} 
competitor is a consumer, too, and his defeat in the competitive fight is more than outbalanced by the fact that, in other markets, he benefits from the quality and low prices which are a result of a competitive fight of other producers. Well, such a conclusion is, at least, speculative. A café owner who goes bankrupt turns out to be without an income and so the high quality and low prices of a majority of products are a poor consolation to him. ${ }^{6}$ A majority of café owners will react to a corporatist plan to create a café guild as follows: I can take care of my business on my own. Such a reaction is a perfect reflection of the individualist ideology. Everybody should mind his own business. The idea that he could make use of the help of other guild members someday in the future is not appealing to this self-made man which is in love with his own independence. And "subsidizing" his "lazy" colleagues? That resembles his independent entrepreneurial spirit of communism. ${ }^{7}$ Nevertheless, lest we do not hide behind an eloquent rhetoric, let us ask directly: what are the guilds good for?

\section{Raison d'etre of Guilds}

Pius XI suggests a corporatist reconstruction of the economic and social order based on a creation of vocational associations. (Quadragesimo anno, 84-85). Why should individuals of the same profession associate, though? After all, every employer is bound in conscience to pay just wages. He does not need to be a member of a guild to do this, though. (Compare Quadragesimo anno, 76). An argument of a possibility of mutual insurance can be attacked by a counterargument that this service is provided by the state social network nowadays. Besides, interests of producers in the same industry are, from a certain viewpoint, in a mutual conflict because a profit of one is a loss of another one. Well then, the main reason of existence of the guilds is, in my opinion, nowadays, the support of the family via restriction on the competition on the supply side. What's the connection? A well-functioning family constitutes a foundation of the state. As such, a well-functioning family is a common good. Securing the conditions under which a family can be well-functioning is, as a result, an obligation of the state. What about the free competition on the supply side does not secure such conditions? Well, as we said, the free competition on the supply side makes time and land scarcer. What does a family need to be well-functioning, then? A family is well-functioning if the man performs his role of father breadwinner and husband, if the woman performs her role of mother householdkeeper and wife, if the children are being brought up by their parents. For the woman to perform her role of mother

\footnotetext{
${ }^{6}$ A defeat in a competitive fight may be a consequence of a horizontal expansion of my competitor, of course. A horizontal expansion creates new jobs, though. In that case, a defeated entrepreneur can get employed by his former competitor. However, a defeat in the competitive fight can have another form, too: there are $X$ customers in the market which enable a profitable operation of $Y$ producers, maximum. So, if a new producer enters the market, another producer has to leave the market because the total of customers has not changed. In that case, the defeated producer has no choice but to retrain for another profession by which he loses a possibility to make a living for a long time.

7 Just as the unity of human society cannot be founded on an opposition of classes, so also the right ordering of economic life cannot be left to a free competition of forces. For from this source, as from a poisoned spring, have originated and spread all the errors of individualist economic teaching. Destroying through forgetfulness or ignorance the social and moral character of economic life, it held that economic life must be considered and treated as altogether free from and independent of public authority, because in the market, i.e., in the free struggle of competitors, it would have a principle of self direction which governs it much more perfectly than would the intervention of any created intellect. But free competition, while justified and certainly useful provided it is kept within certain limits, clearly cannot direct economic life - a truth which the outcome of the application in practice of the tenets of this evil individualistic spirit has more than sufficiently demonstrated. (Quadragesimo anno, 88)
} 
householdkeeper and wife and for both the parents to be able to bring up their children, the man needs to bring home such an income which will enable it (called family wage), the woman needs to be at home and both the man and the woman need to have enough time to manage to take care of and bring up the children. Here's the problem, though: as long as the man is making money in the environment of free competition on the supply side, he will neither be able to generate an income which would free up the woman's hands to look after the household and the children, nor will he have enough time to bring up the children together with his wife. The competitive pressure will not allow him to buy the good "leisure time" in such a quantity which would be necessary for the family to be well-functioning. The same can be said about the land. How can the guilds fix this? Let us assume a group of self-employed entrepreneurs who will agree that they will serve the customers only 8 hours a day without Sundays and holidays. As soon as a newcomer into the industry appears who will be willing to serve the customers 12 hours a day, including Sundays and holidays, the incumbents start loosing their market position and finally will be completely crowded out. However, what if the incumbents had a guild which would not allow any newcomers to serve their customers? Then, with the assistance of the state, the guild could preserve the working conditions (8-hour day, no work on Sundays and holidays) in the whole industry. The same holds true for entrepreneurs employers willing to pay just (family) wages to their employees and not requiring more than 8 hours of work per day and closing down on holidays. A newcomer endowed with a cost-reducing production technology will be able to reduce the price of his product. As long as the incumbents want to remain competitive, they also need to cut the price of their product. Since they are not endowed with the cost-reducing technology, though, they have to either reduce their profits or the wages. However, what if the incumbents had a guild which would not allow any newcomers to the industry to employ the labor force? Then, with the assistance of the state, the guild could preserve both the adequate profits and just (family) wages.

In case of entrepreneurs-employers, a laissez-faire opponent objects, such a system will lead to a stagnation (e. g. Ogilvie, 2014, p. 186). Without the competitive pressure to reduce costs, the entrepreneurs will have no motivation to innovate and search for more economical methods of production. To this I can say: yes, the competitive pressure and the danger of a loss of the status are a powerful engine of the economic growth but they are not the only engine. Another engine of the economic growth is human laziness which is a constant phenomenon across economic systems. Human laziness can explain such technological innovations as a wheel, a steam engine or a combustion engine. It can explain organizational innovations, too: a better organization of labor gives more leisure time ${ }^{8}$ If we return to the objection that payment of just wages is possible without the guilds, too, if only the employers are motivated by internal sanctions, then we can say: yes. In principle, yes. However, an employer who wants to apply the principle of legal or social justice in the wage relation will not be competitive if his competitors are allowed to pay lower than just wages. To the objection of the state social network, we can respond by a reference to the subsidiarity principle. (Quadragesimo anno, 80). That interests of producers in the same industry are mutually in conflict is only true in a limited degree. An interest in good legislation is shared by all producers in the industry and there is no conflict here. As concerns the zero-sum game argument in case of profit and loss, this does not always need to be the case. If the demand is sufficient to enable operation of all incumbents in the industry with an adequate (or just) profit, there is no conflict of interests, provided that the incumbents do not

${ }^{8} \mathrm{~A}$ hypothesis that the guild system had a positive effect on innovations is advocated by e. g. Epstein (1989). 
pursue the goal of a maximum profit but an adequate (or just) profit. ${ }^{9} \mathrm{Next}$, a guild can provide its members with administrative support and tax consultancy. The guild can also help its members as an intermediary in the labor market etc.

A concept of an adequate or fair or just profit is in a strict conflict with the laissez-faire postulate that a producer is a profit-maximizing entity, of course. That an entrepreneur could be happy with a lower profit than that which he could achieve? This sounds like a ridiculously naïve idea. And still, an entrepreneur following the teaching of the Catholic Church, will act exactly like this. First of all, he will take care that he pays just wages to his employees. If he is left with more than what he needs to preserve his economic status corresponding to his station, he will grant the rest to the Church or as alms to the poor (compare Gordley, 1998, p. 11). How different this life philosophy is from that of the ambitious, independent profit-maximizing self-made man which reinvests his profit to make a bigger profit in the next period which will enable him to expand horizontally and vertically and make even bigger profits. For this kind of people, a concentration of economic power is consumption sui generis, that is why this case does not falsify the general rule that consumption is the goal of all production. Now, a laissez-faire opponent can object that the goal of economics is to analyze people as they are in reality, not as they should be. Let us say so. However, the modern economics, incessantly repeating that the goal of a producer is profit maximization, is retroactively shaping the self-perception of the producer who - under the influence of economics - grasps this statement, positive as it originally was meant to be, as normative ${ }^{10}$ : it is natural and, in effect, right if a producer maximizes profit. The producer thus maximizes profit because he considers it natural and, in effect, right: his actions reflect his values. (Yuengert, 1996, p. 100). We can only keep asking: would the producers be maximizing profit if the economists were repeating incessantly that it is natural and, in effect, right, if a producer strives for a just profit?

A laissez-faire opponent will argue, though, that reinvestment of profits (capital accumulation) accompanied by a horizontal expansion is a necessary condition of a technological progress. It may not be relevant in such an industry as cafés but, for example in the transportation industry, we would still be using carriages without the capital accumulation. We can challenge this argument by a reference to history. In the railroad industry, extremely high capital investments were necessary. These were financed through bank credits, though, not through reinvested profits. The development of the car industry, for example, did not require extreme capital investments in its beginnings (Sparkes, 2020). So, horizontal expansion does not need to be financed by the own capital and, at the end of the day, does not even need to be accompanied by the horizontal integration (absorption of competitors). Still, though, if the guild were not allowing a horizontal expansion, factory production would never have emerged which is, thanks to the economies of scale, reducing costs and, in effect, price and, in effect, makes the products available to the poorest ones. There is no big space for increasing the labor productivity in the sector of services. A café, a hairdresser or a notary have only a little bit higher productivity of labor than a century ago. However, in the productive industries, the influence of technological progress allowed by the capital investments is significant. To prevent horizontal expansion in these industries would be unwise because it would deprive the poorest ones of the possibility to keep buying a cheap production of medium quality. Nevertheless, while the horizontal expansion together with lowering the number of producers in the industry increases the number

\footnotetext{
${ }^{9}$ Nevertheless, even if some producers were pursuing the goal of maximum profit and wanted to expand horizontally, there does not have to be a conflict of interests because the defeated producers can be employed by the expansive producers, so that they will not lose the possibility to make a living in the industry.

10 Yuengert (1996, p. 104) talks about the effect of the rhetoric of economics on social mores.
} 
of wage jobs - and, in effect, does not deprive the defeated producers of the possibility to make a living in the industry - entrance of new producers to the industry, with the unchanged market demand, leads to a part of the incumbents being forced to leave the industry without new wage jobs being created. An entrance of new producers to the industry is thus a kind of competition which deprives the defeated producers of the possibility to make a living in the industry and forces them to a costly retraining. A retraining process means very often a loss of income for several years which is ruining a good operation of a well-functioning family. This is why the guild system needs to control the entrance of new producers to the industry and allow an entrance of a new producer only when an incumbent leaves the market voluntarily or when the market demand increases. This is why the membership in the guild cannot be voluntary but needs to be obligatory (Storck, 2020).

If we said that the support of the family by means of the restriction on the competition on the supply side is a common good, this does not mean that the economy should be structurally conserved, of course. It is impossible to emphasize this point sufficiently. The economy is naturally undergoing structural changes - as a result of changes in the consumer preferences. Some industries are expanding, other industries are shrinking. Exactly here, though, the guilds which control the entrance to the industry are an essential institution which ensures that the process of the structural changes is as smooth as possible. If an industry shrinks, as a result of lower market demand, the guild will not accept new members and, along with the incumbents physically dying out as the time goes by, the supply will smoothly keep adjusting to the demand, with respect to the protection of a well-functioning family.

How about transferring the production into developing countries with cheaper labor force, then? The guild system presupposes that the initiative of paying the family wages originates in the entrepreneurs themselves, not in the state. As long as the entrepreneurs want to pay family wages, they have no reason to transfer the production into the developing countries. As long as they do not want to pay the family wages, the guild system will not arise, anyway. There is absolutely no sense for the state to motivate the entrepreneurs by allowing them to shift the higher wage costs onto the consumer. This would reduce the purchasing power of the family wages and the effect of the imposition of the family wages would be neutralized (for a detailed exposition see Máslo, 2021, p. 41). The state can motivate the entrepreneurs institutionally, though. In exchange for the consent to the lower profit margins, the state will provide a guarantee to the entrepreneurs that the competition in the industry will be moderated. Now, if a sufficiently high number of the entrepreneurs appears who will be willing to pay family wages, then the other entrepreneurs will be forced to join them, too, because the membership in the guild is the condition of the production in the industry. Against this a laissez-faire opponent will object: not allowing the cheaper foreign competition to enter the domestic market will take jobs from the population of the developing countries. The employees in the developing countries do not get even a fraction of the just (family) wage, of course. However, these people could work in the agriculture. Here they would earn substantially less money as compared to the jobs from the foreign employers, of course. However, they would keep spending the working time with their children and they would not have to leave the upbringing of their children to other people (or to even send them to work for a wage). Despite a lower income and lower consumption of leisure time, they would be working in an institutional environment which allows a family to keep functioning as a family (see also Máslo, 2021, p. 43).

Another objection is that of "no free lunch": if the employees are getting higher real wages and the employers will enjoy the advantages of the guaranteed market position, who will bear the costs, then? I respond: yes, there is no free lunch. The employers are facing a following trade- 
off: in exchange for a possibly high but uncertain profit margin they will receive a lower but certain profit margin. ${ }^{11}$ It is not true, though, that the family wages are higher only in nominal terms. That would be true if the employers were projecting higher wage costs into the prices to not have to lower their profit margins. However, if the employers will be willing to reduce their profit margins in exchange for the guaranteed market position, then the purchasing power of the wages increases indeed.

A laissez-faire opponent can bring up another objection, though: the guild system keeps binding scarce resources in the production processes which are less efficient than they would be if there were no guilds. If the guild system did not exist, the market would allocate the scarce resources to those producers which are able and willing to pay the market price or higher for them. Now, only those producers are able and willing to pay the market price of higher for the scarce resources which can generate some profit in the process. These are the producers who succeed in the market. These are the producers who are selling their product for the market price or lower. However, only those producers can be selling their product for the market price or lower and generate some profit in the process which are producing that what is being demanded and which are doing so in the most cost efficient way. In the guild system, though, many producers which could supply their product cheaper and at the equivalent quality do not get a chance to do so. This is allocational-inefficient says the laissez-faire opponent. Well, as we have already pointed out, the horizontal expansion is not principally incompatible with the guild system. If an incumbent can find a way to produce his product cheaper and at the equivalent quality and, at the same time, to make employees out of his former competitors in the guild to whom he will be able and willing to pay a just wage, there is no problem here. If he cannot make employees for a just wage out of his former competitors, then his entrepreneurial success will deprive some of his competitors of the possibility to make living in this industry. The allocational efficiency is thus redeemed by the loss of living of the innovator's competitors in this case. The innovator can have his discovery patented, though, and sell the license for this new production process to his competitors in the guild (see Epstein, 1998, pp. 703-704). Why not? Even if the innovator is an outsider, i. e. a non-member of the guild, he can do the same. You can have anything patented. Such an innovator will not enjoy the transitory entrepreneurial profit, that is true, but he will enjoy the incomes from the license. It is obvious, then, that the guild system does not retard or restrict the innovations (Epstein, 1998, p. 684). Sure, the patents are unnecessary in the eyes of the free-marketers. If an innovation generates a profit in itself, then it is unnecessary to protect it by the patent, they argue. If the guild system puts out this compensatory mechanism, though, then a compensation on the basis of licenses is a logical and just solution.

\section{Guilds and Protectionism}

If the point of the guild system is the control of the entry into the industry, then a competition by foreign brands in an industry in which domestic brands exist is incompatible with the guild system. On the other hand, a free entry of foreign brands into an industry in which no domestic brands exist is fully compatible with the guild system. The argument that an import of goods and services takes jobs from the domestic subjects needs to be rejected. In this point, the laissezfaire advocates are right. The import of goods and services results in that these goods and services will not be produced domestically, as a result of what the corresponding jobs will not arise, so far so good. What is not seen, though, said with Bastiat (1850), is that the import of

\footnotetext{
${ }^{11}$ A laissez-faire advocate Hayek (1973, pp. 93-96) talks in this connection contemptuously about "the resentment of the loss of accustomed positions".
} 
goods from abroad releases domestic resources which otherwise would be bound in production of these goods, so that these resources can be used in production of other goods which may be bought exactly by these foreign producers for the incomes from the exports or by some totally different subjects. Until now we can agree with the laissez-faire advocates. We can even agree that the international trade is not a trade between country $A$ and country $B$ but between concrete citizens of country A and concrete citizens of country B. A sum of such individual cross-border contracts determines the structure of the balance of payments. The more citizens of country $A$ trade with citizens of country $B$, the more the commercial interconnectedness increases between country $A$ and country $B$. As long as the relations between the government of country $A$ and government of country $B$ are good, there is no problem. The problem arises at the moment when these relations get worse.

When the government of country B prevents its own citizens from trading with citizens of country $A$, big complications arise to hundreds of thousands and millions of citizens of country $A$ at the stroke of a pen. And to hundreds of thousands and millions of citizens of country $B$, as well, of course. The question is who suffers more by the break-off of the cross-border trading. The international trade creates complex structures of mutual interdependence. We can afford to be dependent of someone, as long as we are in good terms with him and as long as we want to be in good terms with him in the future, too. If the mutual relations get worse, this dependence can be easily used against us. Of course, the mutual commercial interconnectedness decreases the hazard that the relations between the governments could deteriorate because such a deterioration of relations between the governments can escalate to a break-off of mutual trade which is costly for both involved countries. A reduction of the hazard is not a guarantee that this will not happen, though. Partly because the distribution of costs can be asymmetrical (one country will suffer more as result of the break-off of the mutual trade), partly because the priorities of the involved governments may be such that these governments will decide to break off the mutual trade regardless of the costs. If the increase of the mutual interdependence between countries can represent a hazard, the increase in the mutual interdependence between regions of one state is always desirable, on the other hand. It holds true that the more intensive commercial bonds there are between regions in one state, the better. With respect to the territorial integrity of the state, such intensive commercial bonds between regions of one state are a factor which reduces the risk of separatism.

It might seem that the decision of Mr. Smith who is a citizen of country A to buy furniture produced in country B instead of furniture produced in his own country is only concerning Mr. Smith himself. However, at the aggregate level, such individual decisions produce a mutual interdependence between countries. The thing is, if one day the government of country $B$ creates an obstacle to such individual cross-border contracts, the resulting problems of individuals have substantial macroeconomic consequences. Mr. Smith will have to buy furniture in his own country $(A)$, similarly as many other people. The increase in the demand for the furniture produced in country $A$ will be projected into the change in the relative prices, there will be an increase in the demand for wood which will be missing in other industries as a result etc. A worse scenario arrives when the imported good is not produced domestically any more. In that case, a part of resources will need to be diverted to the development of necessary technologies, to the purchases of licenses, to the production of necessary production capacities etc. Shortly speaking, domestic production of these goods will be more expensive. This is always necessary to be born in mind whenever the domestic customers start preferring more price-competitive foreign brands. The more expensive domestic brands will disappear as a result of the decrease in demand. If, then, for any reason (e. g. deterioration of relations between the governments), the foreign brands stop supplying to the domestic market, then, a re- 
substitution of the foreign brands by domestic brands will be accompanied by substantially higher costs than the costs which were saved initially by the purchase of cheaper foreign brands. Break-off of cross-border commercial bonds is a problem for the exporter, too. The dropout of the foreign demand will lead to a decrease in the production and, as a result, a decrease in the employment and, a result, a decrease in demand in other domestic markets etc.

Such calculations cannot be made by any individual customer or producer. Their decision horizon is a short-run horizon. The economic policy of the state needs to be carried out with respect to the long-run horizon, though. To sum up: the international division of labor is compatible with the guild system. With respect to the raison d'etre of the guilds we can say that 1) the state should protect the existing domestic brands from the foreign competition but, at the same time, not prevent foreign brands with no domestic substitutes from entering the domestic market; 2) the state should support the mutual cross-border trade with the countries with which it has the intention to build long-term friendly relations.

\section{Conclusion}

Since consumption is the only purpose and goal of all production, according to the laissez-faire proponents (Smith, 1776), and since everybody is a consumer, then the economic system which is maximizing the well-being of consumers is a common good. Since the well-being of consumers is maximized in a system of free competition on the supply side, then the free competition on the supply side is a common good, according to the laissez-faire proponents. I contend the following.

First, even though a vast majority of goods becomes cheaper as a result of the free competition on supply side, there are two goods which this institutional environment makes scarcer: these goods are time and land. These goods are more available to the consumers in the institutional environment of restricted competition. So, yes, the well-being of some consumers is being maximized in the institutional environment of free competition on the supply side, while the wellbeing of other consumers is being maximized in the institutional environment of restricted competition. So, the inference that free competition is a common good in invalid.

Second, an employer has an obligation to pay his employees a just (family) wage, on the grounds of the legal or social justice (Burke, 2010; Máslo, 2021). A system of free competition may not - and usually will not - make sure that a just wage will be paid. Maximization of a consumer's well-being is a common good but so is justice. I contend that if a consumer's wellbeing comes into conflict with the goal of achieving justice, then it is at least debatable why the consumer's well-being should take precedence.

Third, even though each employer is bound in conscience to pay a just wage and he does not need to be a member of a guild to do this, I argue that the guild system recommended by Leo XIII (Rerum Novarum) and Pius XI (Quadragesimo Anno) has several advantages: as much as payment of a just wage is anchored in the constitution of the guild, the membership in the guild strengthens the good resolution of an individual employer to pay a just wage; the members of a guild can support other members who have suffered an entrepreneurial failure, on a principle of a mutual insurance; a guild can provide its members with an administrative support and tax consultancy; a guild can help its members as an intermediary in the labor market etc. Nevertheless, the primary goal and raison d'etre of a guild is, in my opinion, control of the entrance of new producers to the industry, so that the incumbents who want to pay just (family) 
wages and/or prefer leisure time necessary for operation of a well-functioning family are not forced to change their behavior by the competitive pressure of the newcomers. This, in my opinion, is the common good which Pius XI is talking about in Quadragesimo Anno (85). This way, a smooth process of structural changes in the economy can be achieved. The thing is, unlike the horizontal expansion of some of the incumbents, an entrance of new producers to the industry will, with the unchanged market demand, deprive some of the incumbents of the possibility to make a living in this industry without a simultaneous creation of new wage jobs. Besides, a control of the entrance to the industry will limit the pressure to lower the wages below the level of the just (family) wage. This is why the membership in the guild cannot be voluntary but needs to be obligatory (Storck, 2020). To the objection that control of the entrance to the industry will lead to an economic stagnation (Ogilvie, 2014), I respond that the competitive pressure is only one of the engines of the economic growth. Another engine is human laziness which is constant across economic systems.

Fourth, the state has no tools to force the employers to pay just (family) wages (Worland, 2001) because the employers would project them into their prices and the effect of higher wages would be neutralized (Máslo, 2021). However, the state can motivate the entrepreneurs institutionally. In exchange for the consent to the lower profit margins, the state will provide a guarantee to the entrepreneurs that the competition in the industry will be moderated. To the objection of "no free lunch" I respond: yes, the employers are facing a trade-off. In exchange for a possibly high but uncertain profit margin they will receive a lower but certain profit margin. Now, if a sufficiently high number of the entrepreneurs appears who will be willing to pay family wages, then the other entrepreneurs will be forced to join them, too, because the membership in the guild is the condition of the production in the industry.

Fifth, to the objection of allocational inefficiency and necessary economic stagnation (Ogilvie, 2014) resulting from the guild system I respond: the horizontal expansion is not principally incompatible with the guild system. As concerns innovative newcomers to the industry, the allocational efficiency in the free-competitive environment is redeemed by the loss of living of the innovator's competitors in this case. However, the innovator can have his discovery patented and sell the license for this new production process to his competitors in the guild (Epstein, 1998). What I say is that an external innovator (non-member of the guild) can do the same. Such an innovator will not enjoy the transitory entrepreneurial profit, that is true, but he will enjoy the incomes from the license. It is obvious, then, that the guild system does neither retard or restrict the innovations (Epstein, 1998), nor does it necessarily cause allocational inefficiency.

Sixth, the international division of labor is compatible with the guild system. With respect to the raison d'etre of the guilds I say that 1 ) the state should protect the existing domestic brands from the foreign competition but, at the same time, not prevent foreign brands with no domestic substitutes from entering the domestic market; 2) the state should support the mutual crossborder trade with the countries with which it has the intention to build long-term friendly relations.

\section{References}

Abbott, D. A. (2019). Subjective Values versus Objective Science. International Journal of Social Sciences, Vol. VIII(2), pp. 1-13., DOI: 10.20472/SS.2019.8.2.001.

Bastiat, F. (1850). That Which is Seen, and That Which Is Not Seen. Retrieved from: http://bastiat.org/en/twisatwins.html 
Brown, F. (1996). Catholic Social Teaching and Economic Science. Catholic Social Science Review, 1996, Volume 1, 91-97. Available at: https://doi.org/10.5840/cssr1996113

Burke, J. (2010). Distributive Justice and Subsidiarity: The Firm and the State in the Social Order. Journal of Markets \& Morality, Fall 2010, Volume 13, Number 2, 297-317.

Epstein, S. R. (1998). Craft Guilds, Apprenticeship, and Technological Change in Preindustrial Europe. The Journal of Economic History, September 1998, Vol. 58, No. 3, 684-713.

Gordley, J. (1998). Good Faith and Profit Maximization. Review of Business, Summer 1998, Vol. 19, No. 4., 11-17.

Hayek, F. A. von. (1973). Law, Legislation and Liberty. Routledge, 2003. ISBN 0-415-09868-8.

Keynan, I. (2016). Is neoliberalism consistent with individual liberty? Friedman, Hayek and Rand on education employment and equality. International Journal of Teaching and Education, Vol. IV(4), pp. 30-47. , DOI: 10.52950/TE.2016.4.4.003

Leo XIII. (1891). Rerum Novarum. Retrieved from: http://www.vatican.va/content/leoxiii/en/encyclicals/documents/hf I-xiii enc 15051891 rerum-novarum.html

Máslo, L. A. (2021). A Just Wage: Social Justice in the Labor Market. International Journal of Teaching and Education, Vol. IX(1), pp. 29-48. , DOI: 10.52950/TE.2021.9.1.003.

Ogilvie, S. (2014). The Economics of Guilds. Journal of Economic Perspectives, Fall 2014, Volume 28, Number 4, 169-192. DOI: 10.1257/jep.28.4.169

Pius XI. (1931). Quadragesimo Anno. Retrieved from: http://www.vatican.va/content/piusxi/en/encyclicals/documents/hf p-xi enc 19310515 quadragesimo-anno.html

Smith, A. (1776). An Inquiry into the Nature and Causes of the Wealth of Nations. MetaLibri Digital Library, 2007. Retrieved from:

https://www.ibiblio.org/ml/libri/s/SmithA WealthNations p.pdf

Sparkes, R. (2020). The Recovery of the Guilds. The Distributist Review [online]. March 15, 2020. Retrieved from: https://distributistreview.com/archive/the-recovery-of-the-guilds

Storck, T. (2020). The Place of Guilds in A Distributist Economy. The Distributist Review [online]. July 14, 2020. Retrieved from: https://distributistreview.com/archive/the-place-of-guilds-in-a-distributisteconomy

Worland, S. T. (1981). Exploitative Capitalism: The Natural-Law Perspective. Social Research, Summer 1981, Vol. 48, No. 2, 277-305.

Yuengert, A. M. (1996). Free Markets and Character. Catholic Social Science Review, 1.1 (Fall), 99-110. Available at: https://doi.org/10.5840/cssr1996114 